\title{
Penguatan Wilayah Binaan Mandiri Energi Melalui Peningkatan Kapasitas Mikrohidro di Daerah Terpencil
}

\author{
Strengthening Energy Independent Guidance Areas through Increasing \\ Microhydro Capacity in Remote Areas
}

\author{
Runi Asmaranto $^{1 *}$, Sugiarto $^{2}$, Denny Widhiyanuriyawan ${ }^{2}$, Mangku Purnomo $^{3}$ \\ ${ }^{1}$ Jurusan Teknik Pengairan, Fakultas Teknik, Universitas Brawijaya, Malang 65145, Indonesia \\ ${ }^{2}$ Jurusan Teknik Mesin, Fakultas Teknik, Universitas Brawijaya, Malang 65145, Indonesia \\ ${ }^{3}$ Jurusan Sosial Ekonomi Pertanian, Fakultas Pertanian, Universitas Brawijaya, Malang 65145, Indonesia
}

Article info:

Kata kunci:

energi, pemberdayaan BUMDES, Pokmas pengelola PLTMH.

Keywords:

BUMDES Empowerment, energy, PLTMH Management community group.

Article history:

Received: 01-12-2019

Accepted: 04-04-2020

${ }^{*}$ Koresponden email: runi_asmaranto@ub.ac.id

\section{Abstrak}

Tanah Merah merupakan dusun terpencil di Desa Batur yang belum terjangkau listrik PLN karena letak geografis berada di lereng G. Argopuro dan jauh dari pusat desa. Di Tanah merah telah dikembangkan PLTMH dari debit Sungai Kedung Sumur namun belum optimal. Pernah dilakukan kerjasama oleh BPPM FT UB dengan CSR PT PGN (Persero) tahun 2016, namun belum mampu menyelesaikan terbatasnya daya terbangkit untuk $500 \mathrm{KK}$. Potensi lain masyarakat adalah petani dan peternak. Aktifitas peternakan yang paling bayak dilakukan oleh masyarakat adalah ternak sapi potong sebanyak $267 \mathrm{KK}$ yang rata-rata memiliki 2 ekor sapi. Dengan jumlah ternak sapi yang besar tersebut tentu juga dihasilkan limbah kotoran ternak yang besar juga. Berangkat dari permasalahan yang ada di Dusun Tanah Merah, tim Pengmas Universitas Brawijaya melalui Program Doktor Mengabdi ingin membantu masyarakat mitra menyelesaikan permasalahan yang ada dalam rangka meningkatkan kesejahteraannya. Upaya yang dilakukan adalah pemberdayaan kelompok masyarakat Pengelola PLTMH melalui pemanfaatan energi terbarukan yaitu peningkatan kapasitas listrik mikrohidro dan pemberdayaan ekonomi berbasis mikrohidro.

Abstract
Tanah Merah is an isolated hamlet in the village of Batur that has
not been reached by PLN electricity because its geographical which
is on the slopes of Mount Argopuro and far from the village center.
In Tanah Merah, micro hydro has been developed from the Kedung
Sumur River discharge, but it is not yet optimal. A collaboration
was held by BPPM FT UB with CSR of PT PGN (Persero) in 2016,
but has not been able to resolve the limited power generated for 500
families. Another potential community is farmers and breeders.
Most livestock activities carried out by the community are 267
household averaging 2 cows each. With such many cattle, it is of
course also produced a large amount of livestock waste. Based on
these problems, the UB Community Service Team through the
Serving Doctoral Program wants to help partner communities solve
existing problems to improve their welfare. Efforts are being made
to empower community groups of microhydro (PLTMH) using
renewable energy, namely increasing micro-hydro electricity
capacity and empowering micro-hydro-based economies.

Tanah Merah is an isolated hamlet in the village of Batur that has not been reached by PLN electricity because its geographical which is on the slopes of Mount Argopuro and far from the village center. In Tanah Merah, micro hydro has been developed from the Kedung Sumur River discharge, but it is not yet optimal. A collaboration was held by BPPM FT UB with CSR of PT PGN (Persero) in 2016, but has not been able to resolve the limited power generated for 500 families. Another potential community is farmers and breeders. Most livestock activities carried out by the community are 267 household averaging 2 cows each. With such many cattle, it is of these problems, the UB Community Service Team through the Serving Doctoral Program wants to help partner communities solve existing problems to improve their welfare. Efforts are being made renewable energy, namely increasing micro-hydro electricity 
Kutipan: Asmaranto, R., Sugiarto, S., Widhiyanuriyawan, D., \& Purnomo, M. (2020). Penguatan Wilayah Binaan Mandiri Energi Melalui Peningkatan Kapasitas Mikrohidro Di Daerah Terpencil. Jurnal Teknik Pengairan. https://doi.org/10.21776/ub.pengairan.2020.011.01.03

\section{Pendahuluan}

Energi merupakan faktor penting dalam pertumbuhan dan perkembangan ekonomi suatu Negara (Uddin et al. 2019). Saat ini, tingginya emisi gas rumah kaca telah mendorong perubahan parah di atmosfer. Jadi, penting untuk bergerak maju penggunaan sumber daya energi yang berkelanjutan (Hatata, El-Saadawi, and Saad 2019). Desa Batur Kecamatan Gading merupakan salah satu desa yang berada di wilayah Kabupaten Probolinggo yang berada di lereng Gunung Argopuro dengan Luas wilayah sekitar 436.81 ha (Uddin et al. 2019). Dalam upaya mendukung kebijakan nasional terkait dengan Program Desa Mandiri Energi, pada tahun 2012 Pemerintah Kabupaten Probolinggo bersama masyarakat Desa Batur khususnya masyarakat Dusun Tanah Merah membangun 1 unit Pembangkit Listrik Tenaga Mikrohidro (PLTMH) di Dusun Tanah Merah dengan kapasitas terpasang $16 \mathrm{~kW}$. Dari kapasitas terpasang tersebut daya listrik yang terbangkit baru sekitar maksimum $2.5 \mathrm{~kW}$ dan digunakan untuk memenuhi listrik $30 \mathrm{KK}$ dari $500 \mathrm{KK}$ yang ada. Karena daya listrik PLTMH yang terbatas hanya $2.5 \mathrm{~kW}$, sementara harus mengaliri $30 \mathrm{KK}$ menyebabkan tegangan listrik di malam hari drop/ turun sampai 120 volt. Hal ini berdampak pada lampu dan peralatan elektronik pada malam hari beroperasi dengan kualitas listrik yang tidak optimal. Kapasitas PLTMH yang belum optimal ini disebabkan salahsatunya karena debit air ke turbin belum dioptimalkan. Kondisi saluran pembawa menuju intake sepanjang kurang lebih $30 \mathrm{~m}$ sering mengalami kerusakan akibat banjir dan kurang layak secara teknis, sehingga perlu dilakukan perbaikan (BPS Kabupaten Probolinggo 2017) (Kanal24 2019) (Seru 2019).

Dampak luaran perbaikan PLTMH diharapkan membantu aktifitas kegiatan masyarakat seperti pertemuan warga, mengaji dan lainnya masih terfokus di siang hari karena di malam hari kondisinya masih gelap dengan daya listrik terbatas. Sedangkan pergerakan ekonomi pada masyarakat mitra ini, aktifitas usaha kecil maupun ekonomi kreatif belum terbentuk dan masih bertumpu pada kegiatan pertanian dan peternakan. Berdasarkan hasil survei, aktifitas peternakan yang paling banyak dilakukan oleh masyarakat di dusun ini adalah beternak sapi potong sebanyak 267 kepala keluarga (KK) dengan penyebaran peternak sapi di RT 8 berjumlah 107 KK, RT 9 berjumlah $95 \mathrm{KK}$ dan RT 10 berjumlah $62 \mathrm{KK}$ yang masing-masing kepala keluarga memeliharan rata-rata 2 ekor sapi. Dengan jumlah ternak sapi yang besar tersebut tentu juga dihasilkan limbah kotoran ternak yang besar. Limbah ternak tersebut berpengaruh terhadap kebersihan lingkungan dan kesehatan masyarakat, apalagi penempatan kandang ternak umumnya bedekatan dengan rumah tinggal. Melalui kegiatan pemberdayaan masyarakat, limbah ternak tersebut seharusnya bisa dikelola lebih lanjut berpotensi sebagai sumber energi terbarukan dan sumber pupuk organik. Selain komoditi peternakan, juga terdapat komoditi pertanian seperti padi, jagung, kopi, pisang, cabai dan berbagai sayuran dan buah-buahan. Dalam hal ini ternyata masyarakat belum mampu memberikan nilai tambah terhadap harga jual komoditi pertanian dan peternakan tersebut. Seharusnya dengan komoditi peternakan dan didukung hasil pertanian yang cukup besar menjadi modal yang kuat untuk mendorong masyarakat Tanah Merah untuk hidup lebih sejahtera.

Berangkat dari permasalahan yang di atas, tim Doktor Mengabdi Universitas Brawijaya membantu masyarakat Tanah Merah khususnya dan Pemerintah Desa Batur untuk ikut menyelesaikan permasalahan yang ada dalam rangka meningkatkan kesejahteraannya. Berdasarkan analisis situasi tersebut dapat diidentifikasi permasalahan yang dihadapi oleh masyarakat mitra PKM antara lain (Kanal24 2019) (Seru 2019);

a. Daya PLTMH yang terbangkit masih terlalu kecil sehingga belum mampu memenuhi kebutuhan daya listrik yang diharapkan untuk masyarakat Tanah Merah.

b. Saluran pembawa menuju penstock dengan panjang sekitar $30 \mathrm{~m}$ belum stabil dikarenakan sering rusak terkena banjir jika musim hujan, hal ini menurunkan kinerja PLTMH.

c. Pembagian beban jaringan tidak merata sehingga banyak kebocoran arus dan rawan dari sisi keamanan.

d. Limbah peternakan sapi sangat besar yang dan belum dimanfaatkan secara optimal. 
e. Potensi limbah pertanian memungkinkan dikembangkan untuk produksi kompos, atau pupuk organik

f. Potensi hasil pertanian cukup besar namun belum muncul aktifitas ekonomi kreatif yang mampu meningkatkan nilai tambah terhadap komoditi pertanian dan peternakan.

\section{Bahan dan Metode}

\subsection{Prinsip kerja mikrohidro}

Secara singkat prinsip kerja dari suatu pembangkit PLTM dapat digambarkan sebagai berikut (Dametew 2016) (Hanafi and Riman 2015) (Nasir 2014):

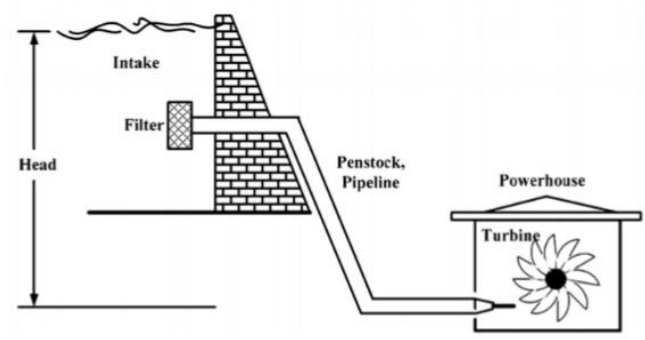

Gambar 1. Prinsip Kerja Suatu PLTM

Dari Gambar 1, maka dapat disimpulkan bahwa suatu pembangkit listrik tenaga minihidro tergantung dengan debit air, ketinggian (jatuh ketinggian) dan efisiensi.

Besarnya daya yang dihasilkan oleh PLTM tergantung dari besarnya head dan debit air. Yang dimaksud dengan head adalah tinggi jatuh efektif sedangkan debit air adalah debit outflow pada intake. Prinsip kerja PLTMH adalah memanfaatkan energi dari aliran air untuk dikonversi menjadi energi listrik. Air yang digunakan bisa diperoleh dengan cara membendung ataupun dengan memindahkan aliran air yang telah ada untuk mendapatkan tinggi jatuh air yang cukup sebagai pebangkit daya listrik.

\subsection{Daya PLTMH}

Besarnya daya hidrolik $(\mathrm{Ph})$ yang merupakan potensi sumber daya energi air pada suatu wilayah, ditentukan melalui persamaan (Uddin et al. 2019) (Hanafi and Riman 2015) (Nasir 2014) (Rizal, Utomo, and Purnomo 2014):

dengan:

$$
\begin{aligned}
& P_{h}=\rho \cdot Q \cdot g H(\text { watt }) \\
& P_{h}=9.8 . \rho Q \cdot H(k W)
\end{aligned}
$$

$\mathrm{P}_{\mathrm{h}}=$ daya hidrolik $(\mathrm{kW})$

$\mathrm{Q}=$ debit air $\left(\mathrm{m}^{3} / \mathrm{s}\right)$

$\rho \quad=$ massa jenis air $\left(1000 \mathrm{~kg} / \mathrm{m}^{3}\right)$

$\mathrm{g} \quad=$ gravitasi bumi $\left(=9,8 \mathrm{~m} / \mathrm{s}^{2}\right)$

$\mathrm{H}$ = tinggi jatuh air (m)

Ada beberapa hal yang berpengaruh terhadap daya keluaran dari sistem PLTMH, selain besarnya debit air dan tinggi jatuh air, daya keluaran tergantung dari efisiensi kincir/ turbin, efisiensi transmisi mekanik, rugi-rugi aliran pada pipa pesat, dan efisiensi generator yang dipakai. Jika efisiensi pipa pesat $\left(\eta_{\mathrm{pp}}\right)$ dan efisiensi turbin $\left(\eta_{\mathrm{tb}}\right)$, maka besarnya daya mekanik turbin dapat ditentukan dari persamaan (Nasir 2014) (Gagliano et al. 2014) (Rizal, Utomo, and Purnomo 2014):

$$
P_{t b}=\eta_{t b} \cdot \eta_{p p} \cdot P_{h}(\mathrm{~kW})
$$

Apabila antara turbin dengan generator terdapat perangkat sistem transmisi mekanik $\left(\eta_{\mathrm{tm}}\right)$, dan efisiensi generator $\left(\eta_{\mathrm{g}}\right)$ diketahui, dapatlah ditentukan besarnya daya keluaran elektrik dari generator, melalui persamaan:

$$
P_{\text {out }}=\eta_{t m} \cdot \eta_{g} \cdot P_{t b} \quad(\mathrm{~kW})
$$

Atau: 


$$
P_{\text {out }}=\eta_{\text {total }} \cdot P_{h} \quad(\mathrm{~kW})
$$

Sehingga:

$$
P_{\text {out }}=\eta_{\text {total }} \cdot \rho \cdot Q \cdot g \cdot H \quad(\mathrm{~kW})
$$

Dalam hal ini, $\eta_{\text {total }}$ adalah efisiensi total sistem mulai dari turbin sampai dengan generator dirumuskan $\left(\eta_{t o t a l}=\eta_{p p} \cdot \eta_{t b} \cdot \eta_{t m} \cdot \eta_{g}\right)$. Sedangkan $\eta_{p p} \cdot \eta_{t b}$ dikenal pula dengan istilah efisiensi mekanik $\left(\eta_{\text {mek }}\right)$.

\subsection{Pemberdayaan Ekonomi berbasis PLTMH}

Pemberdayaan bisa diartikan sebagai proses, cara, perbuatan, memberdayakan. Menurut Ginandjar Kartasasmita, pemberdayaan ekonomi rakyat adalah "Upaya yang merupakan pengerahan sumber daya untuk mengembangkan potensi ekonomi rakyat untuk meningkatkan produktivitas rakyat sehingga, baik sumber daya manusia maupun sumber daya alam di sekitar keberadaan rakyat, dapat ditingkatkan produktivitasnya". Dalam kegiatan pemberdayaan ekonomi berbasis PLTMH ini adalah melakukan identifikasi potensi ekonomi yang bisa dikembangkan oleh kelompok masyarakat Mitra dalam hal ini adalah pengelola mikrohidro Tanah Merah. Pada saat siang hari dimana masyarakat tidak banyak menggunakan energy listrik mikrohidro, maka sisa energy (dummy load) yang ada bisa digunakan untuk peningkatan ekonomi kreatif, meningkatkan pendapatan sehari-hari yang dikelola bersama. Contoh kegiatan yang bisa dilaksanakan adalah usaha bengkel las listrik, pertukangan/mebel menggunakan alat serut dan pasrah listrik, pengupasan atau sangria kopi menggunakan listrik mikro hidro. Sehingga perlu dilakukan analisis SWOT terhadap potensi sebagai kekuatan, kelemahan, peluang dan ancaman yang ada dalam pemberdayaan ekonomi (Sanito et al. 2020).

Selain potensi diatas, perlu upaya pengembangan BUMDES (Badan Usaha Milik Desa) dimana keberadaannya semakin diperhitungkan setelah KUD (Koperasi Unit Desa) yang sebelumnya sulit untuk berkembang. Pengelolaan BUMDES benar-benar berasal dari masyarakat dan untuk masyarakat. Beberapa potensi yang bisa dikembangkan adalah potensi pertanian, perkebunan, peternakan, perikanan, dll sesuai dengan kearifan lokal masing-masing daerah.

\subsection{Metodologi}

Studi kasus ini didasarkan pada studi lapangan dan menggunakan kombinasi pendekatan kuantitatif dan kualitatif (Kanal24 2019) (Sovacool 2013). Metode kualitatif dipilih karena sesuai untuk menangani langsung persepsi responden (Sovacool 2013) sedangkan metode kuantitatif digunakan untuk melengkapi temuan dari wawancara. Penerapan metodologi dilakukan dengan cara social partisipatif dimana kegiatan pemberdayaan masyarakat dilakukan dengan melibatkan seluruh komponen khususnya kelompok mitra yaitu pengelola PLTMH Dusun Tanah Merah. Tujuannya adalah untuk menjamin keberlanjutan kegiatan, karena dengan melibatkan masyarakat akan diperoleh tingkat kepuasan yang lebih baik, dan masyarakat mitra merasa memiliki aset-aset yang diserahkan oleh pelaksana. Pada tahapan akhir dilakukan analisis SWOT (Sanito et al. 2020), untuk mengetahui kondisi kekuatan, kelemahan, peluang dan ancaman terkait kondisi kelompok masyarakat mitra PLTMH dan menemukan strategi penaganannya. Pelaporan kegiatan dilakukan dengan metode analisis deskriptif berdasarkan kondisi internal dan eksternal masyarakat mitra. Secara garis besar metodologi yang dilakukan melalui 4 tahapan yaitu persiapan, pengumpulan data primer dan sekunder, analisis data dan perencanaan, analisa hasil kegiatan dan pembahasan serta pengambilan kesimpulan.

\section{Hasil dan Pembahasan}

\subsection{Perbaikan Saluran Pembawa}

Berdasarkan hasil survei dilapangan, diketahui bahwa untuk memperbaiki saluran pembawa menuju intake diperlukan konstruksi yang kuat, murah dan tahan lama. Mengingat material yang ada dilokasi mitra binaan adalah batu berukuran boulders, maka diusulkan konstruksi perkuatan berupa bangunan bronjong/gabion berukuran $2 \times 1 \times 0.5 \mathrm{~m}$ yang disusun sepanjang $30 \mathrm{~m}$ dengan dilapisi bahan sederhana berupa karung beras bekas untuk mencegah kehilangan air pada lubang 
bronjong. Pekerjaan dengan melibatkan masyarakat mitra sebagai berikut (Kanal24 2019) (Seru 2019).

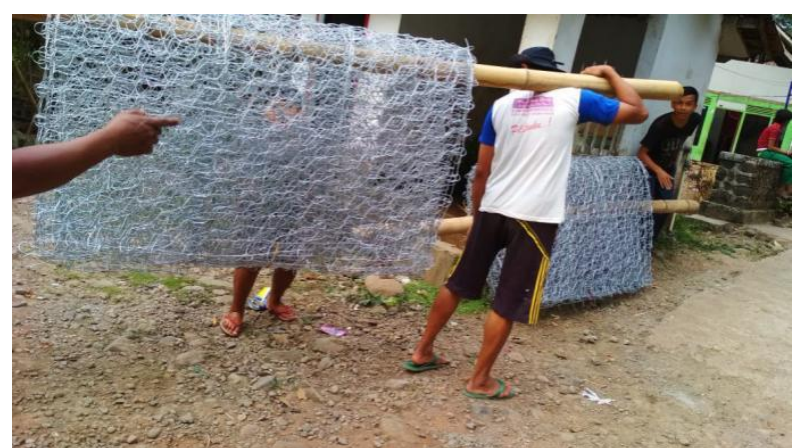

Gambar 2. Fabrikasi dan langsir material dengan berjalan kaki sejauh 2,5 km ke lokasi Mitra DM

Berdasarkan hasil evaluasi kondisi sebelum dan sesudah pembangunan saluran pembawa, maka terlihat ada peningkatan debit inflow menuju intake sebesar $10 \%$ pada musim kemarau, dengan analisis sebagai berikut:

Data teknis setelah perbaikan:

Lebar saluran, $\quad b=1 \mathrm{~m}$

Tinggi air, $\quad \mathrm{h}=0.20 \mathrm{~m}$

Luas Penampang basah,

$$
\mathrm{A}=0.20 \times 1=0.20 \mathrm{~m}^{2}
$$

Jari-jari hidrolis,

$$
\begin{gathered}
\mathrm{P}=1+(2 \times 0,20)=1.4 \mathrm{~m} \\
\text { Kecepatan, } \quad \mathrm{v}=1 / \mathrm{n} . \mathrm{R}^{2 / 3} \cdot \mathrm{S}^{1 / 2} \\
=1 / 0.025 \cdot(0.20 / 1.4)^{2 / 3} \cdot(1 / 100)^{1 / 2}=1.093 \mathrm{~m} / \text { detik. } \\
\begin{array}{c}
\text { Debit aliran, } \quad \mathrm{Q}=\mathrm{V} \cdot \mathrm{A}=1.093 \times 0,20 \\
=0.218 \mathrm{~m}^{3} / \text { detik }=218 \text { liter/detik }
\end{array}
\end{gathered}
$$

Berdasarkan rumus daya listrik yang dibangkitkan maka, daya bisa dihitung sebagai berikut (Nasir 2014; Gagliano et al. 2014; Patty 1995) :

$\mathrm{P}_{\mathrm{h}}=9.8 \times \mathrm{Q} \times \mathrm{H}(\mathrm{kW})=9.8 \times 0.218 \times 6=12.85 \mathrm{~kW}$

$\mathrm{P}_{\text {out }}=\eta_{\text {total }} \times 12.85=0.60 \times 12.85$

$\mathrm{P}_{\text {out }}=7.71 \mathrm{~kW}$

Jadi daya listrik yang dibangkitkan efektif sebesar $7.71 \mathrm{~kW}$ dari kapasitas sebelumnya pada kondisi debit minimum hanya mencapai 2 hingga $3 \mathrm{~kW}$, sementara kapasitas generator terpasang adalah 12 $\mathrm{kW}$.
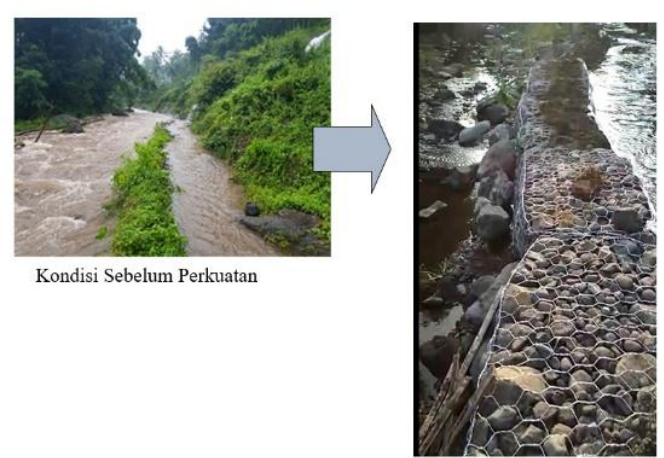

Kondisi Sesudah Perkuatan

Gambar 3. Perbaikan saluran pembawa dengan kombinasi bronjong dan karung bekas untuk penanganan perkuatan dan rembesan. 

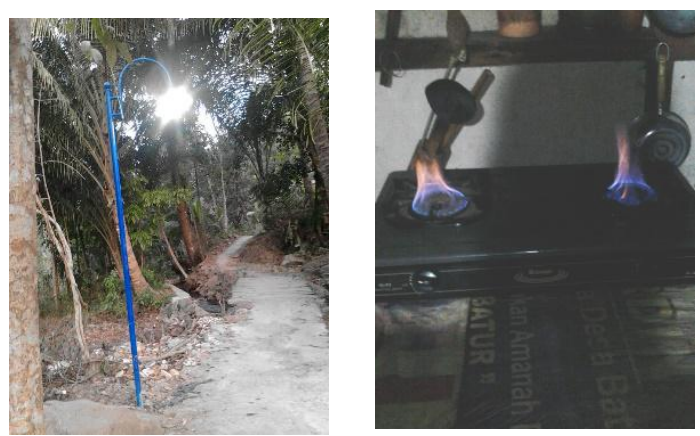

Gambar 4. Penerapan Teknologi Tepat Guna (TTG) lampu penerangan jalan dan kompor biogas di lokasi mitra.

\subsection{Pemberdayaan Ekonomi Mitra Pokmas}

Berdasarkan hasil survei, kajian dan analisis SWOT di lokasi Mitra Doktor Mengabdi adalah sebagai berikut:

a. Strength (kekuatan)

1. Kelompok masyarakat pengelola PLTMH Tanah Merah sudah mempunyai organisasi yang saling percaya antara ketua dan anggota

2. Sudah terbentuk BUMDES di Desa Batur

3. Mempunyai kemauan tinggi untuk maju dan mengembangkan diri

4. Potensi desa dalam bidang pertanian dan perkebunan belum dikembangkan diantaranya: gula aren, kopi, pisang, jagung, ketela, janggelan, durian, kayu sengon, dll

5. Potensi peternakan yang belum dikembangkan : penggemukan sapi potong, sementara ketersediaan pakan berlimpah

6. Potensi debit Sungai Kedungsumur cukup besar untuk pengembangan PLTMH

b. Weakness (Kelemahan)

1. Organisasi kelompok masyarakat Pengelola PLTMH Tanah Merah belum berbadan hukum

2. Organisasi BUMDES belum berbadan hukum

3. Akses menuju lokasi mitra belum sepenuhnya bisa dijangkau kendaraan roda 4 (empat)

4. Kemampuan sumberdaya manusia masih terbatas, jaringan bisnis terbatas

c. Opportunity (Peluang)

1. Potensi wisata air panas di Desa Batur yang belum dikembangkan oleh Pemerintah Daerah Probo-linggo

2. Potensi pengembangan pember-dayaan masyarakat pengelola PLTMH oleh CSR PJB dan PLTU Paiton yang tidak jauh dari lokasi mitra.

3. Pemandangan alam yang merupakan aset tak ternilai bagi pemerintah daerah.

d. Threat (ancaman)

1. Kerusakan lingkungan akibat pembuangan kotoran hewan sapi yang belum dimanfaatkan

2. Potensi kerusakan daerah aliran sungai akibat panen kayu sengon secara masal di hulu daerah aliran sungai (DAS).

Berdasarkan analisis SWOT diatas maka disusun beberapa strategi sebagai berikut:

a. Strategi SO (strength-opportunity)

1. Pendampingan Penguatan kelembagaan/organisasi BUMDES dan pokmas, penguatan struktur organisasi, job deskripsi, system koordinasi, aturan kerjasama dengan pihak ketiga

2. Pendampingan penyusunan rencana usaha berbasis potensi dan kebutuhan, system informasi dan pembukuan, pedoman $\mathrm{AD} / \mathrm{ART}$.

b. Strategi ST (strength-threat)

1. Pengeloaan kandang sehat dan pengembangan BIOGAS kotoran sapi.

2. Pemanfaatan budidaya perikanan berbasis limbah BIOGAS

3. Reboisasi tanaman buah berakar tunjang pada daerah hulu

4. Minimaliasi panen kayu sengon secara bersamaan di kawasan hulu, sehingga tidak menyebabkan banjir bandang. 
c. Strategi WO (weakness-opportunity)

1. Bekerjasama dengan pemerintah daerah dan CSR serta BUMN untuk peningkatan kawasan wisata

2. Perbaikan infrastruktur sarana dan prasarana jalan sebagai akses utama

d. Strategi WT (weakness-threat)

1. Sosialisasi pentingnya kawasan lindung, kawasan sempadan sungai dan potensi bahaya (hazard) landslide akibat penggundulan hutan

2. Peningkatan sumberdaya manusia melalui penguatan kader lingkungan desa.

\subsection{Pelatihan dan Penyerahan Alat ke Masyarakat Mitra}

Pada kegiatan ini telah dilakukan kegiatan pelatihan pembuatan pakan ternak sapi dan pemberdayaan BUMDES yang diikuti oleh anggota pokmas PLTMH dan BUMDES Batur, yang dilaksanakan di Laboratorium Agrotechnopark UB. Pada kegiatan ini dilakukan praktek pencampuran konsentrat untuk pakan sapi yang terdiri dari: Polar, dedak padi, garam dan pencampuran menggunakan mesin Chopper. Pada kegiatan Doktor mengabdi sebelumnya dan tahun 2019 ini juga diterapkan Teknologi Tepat Guna (TTG) dan diserahkan beberapa peralatan sebagai berikut (Kanal24 2019) (Asmaranto 2018).

a. Teknologi tepat guna untuk pencacah kompos melalui penyerahan Mesin Chopper kapasitas $150 \mathrm{~kg} / \mathrm{jam}$ beserta mesin penggerak $8 \mathrm{HP}$

b. Alat pertukangan berupa mesin las listrik, mesin serut listrik, mesin gerinda, kabel jaringan dan lampu penerangan.

c. Teknologi Tepat Guna, Digester biogas untuk kompor biogas dan lampu penerang sejumlah 1 unit.

d. Teknologi tepat guna lampu penarangan jalan, beserta tiang penyangga sejumlah 20 unit untuk penerangan di malam hari.

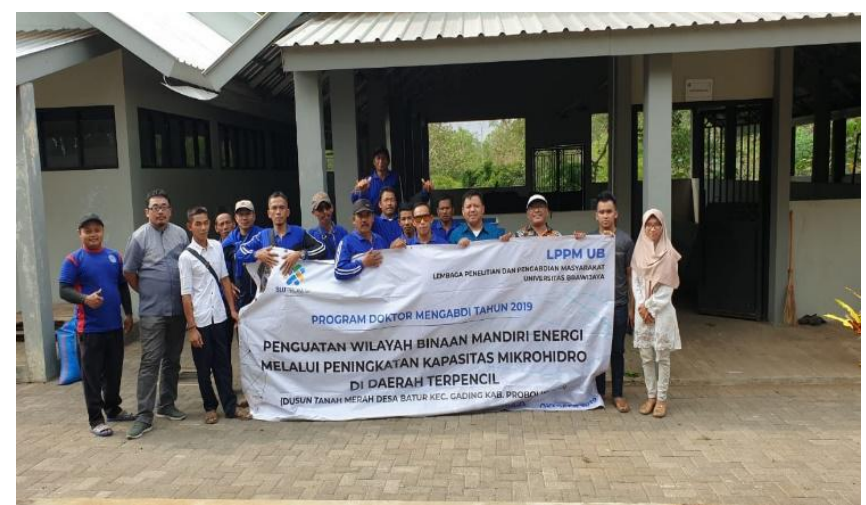

Gambar 5. Pelatihan pembuatan pakan ternak sapi, dan pemberdayaan BUMDES di Laboratorium Agrotechnopark UB.

\section{Kesimpulan}

Kegiatan penguatan wilayah binaan mandiri energi sangat perlu dilakukan mengingat keterbatasan energi fosil yang semakin habis. Potensi desa yang belum dikembangkan sangat perlu diolah menggunakan potensi energi lokal seperti, mikro hidro, solar cell, biogas kotoran hewan, biogas sampah, dll sehingga ketergantungan masyarakat terhadap bantuan pemerintah semakin berkurang. Pemberdayaan Badan Usaha Milik Desa juga perlu pendampingan supaya mencapai kemandirian ekonomi berbasis potensi kearifan lokal masing-masing wilayah.

\section{Ucapan terima kasih}

Terima kasih yang sebesar-besarnya disampaikan kepada Rektor Universitas Brawijaya, Ketua LPPM UB, Dekan FT UB sebagai fasilitator kegiatan doktor mengabdi, seluruh tim pelaksana kegiatan atas kerjasamanya yang baik dan kepada masyarakat mitra khususnya pengelola PLTMH Tanah Merah dan masyarakat Desa Batur. 


\section{Daftar Pustaka}

Asmaranto, Runi dkk. 2018. Menuju Masyarakat Sejahtera Melalui Penyediaan Energi Mandiri Di Daerah Terpencil. Laporan Pengabdian Kepada Masyarakat Program Doktor Mengabdi.

BPS Kabupaten Probolinggo. 2017. Kabupaten Probolinggo Dalam Angka Tahun 2017. ed. Kabupaten Probolinggo. Kabupaten Probolinggo: Kabupaten Probolinggo.

Dametew, Alie Wube. 2016. "Design and Analysis of Small Hydro Power for Rural Electrification Chapter-One." Global Journal of Researches in Engineering.

Gagliano, A., G. M. Tina, F. Nocera, and F. Patania. 2014. "Technical and Economic Perspective for Repowering of Micro Hydro Power Plants: A Case Study of an Early XX Century Power Plant." In Energy Procedia,.

Hanafi, Jessica, and Anthony Riman. 2015. "Life Cycle Assessment of a Mini Hydro Power Plant in Indonesia: A Case Study in Karai River." In Procedia CIRP,.

Hatata, A. Y., M. M. El-Saadawi, and S. Saad. 2019. "A Feasibility Study of Small Hydro Power for Selected Locations in Egypt." Energy Strategy Reviews.

Kanal24. 2019. "Belum Semua Menikmati Listrik, Tim DM UB Tingkatkan Kapasitas PLTMH." http://kanal24.co.id/read/belum-semua-menikmati-listrik-tim-dm-ub-tingkatkan-kapasitaspltmh.

Nasir, Bilal Abdullah. 2014. "Design Considerations of Micro-Hydro-Electric Power Plant." In Energy Procedia,.

Rizal, Firmansyah, Teguh Utomo, and Hery Purnomo. 2014. "Perancangan Pembangkit Listrik Tenaga Mikrohidro Gunung Sawur Unit 3 Lumajang." Perancangan Pembangkit Listrik Tenaga Mikrohidro Gunung Sawur unit 3 Lumajang.

Sanito, Raynard Christianson, Sheng Jie You, Tien Jin Chang, and Ya Fen Wang. 2020. "Economic and Environmental Evaluation of Flux Agents in the Vitrification of Resin Waste: A SWOT Analysis." Journal of Environmental Management.

Seru. 2019. “Tingkatkan Kapasitas Mikro Hidro, Tim Doktor Mengabdi UB Sukses 'Terangkan' Tanah Merah.” http://seru.co.id/tingkatkan-kapasitas-mikro-hidro-tim-doktor-mengabdi-ubsukses-terangkan-tanah-merah/.

Sovacool, Benjamin K. 2013. "A Qualitative Factor Analysis of Renewable Energy and Sustainable Energy for All (SE4ALL) in the Asia-Pacific." Energy Policy.

Uddin, Waqar et al. 2019. "Current and Future Prospects of Small Hydro Power in Pakistan: A Survey." Energy Strategy Reviews. 